Artículo Científico Original

$$
\begin{aligned}
& \text { TRABALHÓPOCA COLONIAL - UM PADRÃO A PARTIR } \\
& \text { DO CASO PORTUGUÊS? }
\end{aligned}
$$




\section{TRABALHO FORÇADO NA ÉPOCA COLONIAL - UM PADRÃO A PARTIR DO CASO PORTUGUÊS?*}

\section{FORCED LABOUR IN THE COLONIAL ERA - A PORTUGUESE PATTERN?}

Maciel Santos

Investigador do CEAUP (Centro de Estudos Africanos da U. Porto): Professor do Departamento de História da Faculdade de Letras da U. Porto.

\section{RESUMO}

Na Africa subsaariana, o trabalho forçado durou, com graus de intensidade e extensão geofráfica variáveis, mais de meio milénio (1440-1960). As suas modalidades - do tráfico atlântico de escravos às últimas formas da legislação laboral colonial - têm características comuns, sendo a principal o facto de estas práticas terem sido condicionadas pelas necessidades da produção para $\circ$ mercado mundial.

A última fase, a do trabalho sob as administrações coloniais, é a menos conhecida. Através de dois exemplos localizados na área colonial portuguesa (as plantações de cacau em S. Tomé e Príncipe e a cobrança do imposto no norte de Moçambique) tenta-se sintetizar um padrão das práticas coloniais de trabalho forçado. Um padrão do trabalho forçado passado pode ter utilidade prática perante as realidades contemporâneas do trabalho escravo.

Palavras-chave: Trabalho Forçado, escravidão, legislação laboral colonial.

\section{ABSTRACT}

Forced labour in Africa has endured more than five centuries (1440-1975). Its different historical features - from the Atlantic slave trade to the late colonial law - have notwithstanding some common marks. The main one relates to the fact that all of them were designed to match the world market demands.

The last years of African forced labour, under colonial rule, are far less known than the slavery or the slave trade times. This article tries to set a pattern of the colonial labour practice based on two Portuguese cases (the cocoa plantations in S. Thome and the tax collection in northern Mozambique). A pattern of past forced labour is doubtless useful to face today's slave labour.

Key Words: Forced Labour, slavery, Colonial Law. 


\section{Trabalho forçado em África - quando e onde?}

Na África sub-saariana, a generalização do trabalho forçado começou sob a forma do tráfico de escravos (c.1440-1860) e acabou quando o trabalho compelido colonial teve as suas últimas abolições (iá na década de 1960). Durante este longo período a coação para aproveitamento de uma força de trabalho fez-se sem solução de continuidade. Isto porque quando na década de 1860 o tráfico atlântico terminou no litoral da África Ocidental (incluindo as suas extensões em Moçambique), já várias sociedades escravagistas africanas se desenvolviam na base de exportações para os mercados europeus'. Em muitos casos portanto, a instalação dos poderes coloniais nessas regiões, que as fez entrar num segundo período de trabalho forçado, apenas aumentou, na base de uma regulamentação laboral "especial", a escala do fenómeno. Pode assim falar-se de cerca de cinco séculos de trabalho forçado ininterrupto em grande parte do continente africano.

Este processo histórico apresenta características estruturais comuns, sem dúvida úteis para uma melhor compreensão dos traços contemporâneos deste tipo de práticas. Podem resumir-se as características estruturais do trabalho forçado africano nos seguintes 5 pontos:

1 - Todas as modalidades de trabalho forçado que em África foram - direta ou indiretamente e independentemente do seu regímen jurídico de enquadramento - desenvolvidas pelos europeus, evoluíram exclusivamente em função do modo capitalista de produzir. Isto é, tanto o comércio de escravos para as Américas como depois a produção de mercadorias "lícitas" na Africa Central e Ocidental (oleaginosas,

Lovejoy descreveu as dos emiratos da futura Nigéria. LOVEJOY,2000. Para a políticas da administração colonial francesa perante o que "encontrou" na região da A.O.F., SURET-CANALE, 1964. algodão, cacau, ouro, etc.) se fizeram com o objectivo de obter mercadorias e lucros.

Os antropólogos não têm dificuldade em reconhecer a diferença entre esta maneira de produzir, que visa acumular capital, com outras que em África também usavam "escravos" mas não produziam mercadorias ou, se o faziam, onde o uso de escravos não era determinante. Nas sociedades tradicionais existia uma grande variedade de formas de coação do trabalho: ia da dependência parental (em muitos casos, a chamada escravatura doméstica) às corveias e impostos exigidos a grande parte da população nas chamadas sociedades tributárias ${ }^{2}$. No entanto, as duas principais diferenças relativamente ao modo capitalista de utilizar escravos parecem ser as seguintes: os trabalhadores dependentes (termo menos ambíguo que escravos) das sociedades pré-capitalistas não eram eles próprios mercadorias ${ }^{3}$ e, quando o eram, serviam para produzir bens e serviços não comercializados - isto é, não-mercadorias.

2 - Durante o período em que populações africanas foram compelidas ao trabalho - em particular nos ramos agrícola e mineiro - a composição orgânica do capital foi baixa. Por outras palavras, o modo capitalista de produzir utilizava então, relativamente ao período actual, muito mais trabalho vivo (força de trabalho) do que morto (materiais, instrumentos, informação).

Na produção capitalista não são conhecidos casos de utilização sistemática de trabalho escravo em ramos de composição orgânica elevada ou exigindo uma formação complexa da força de trabalho, tanto quanto estas duas características vão a par uma da outra. A principal razão deve-se ao facto de os escravos-mercadorias te- 
rem sempre um custo de aquisição. Ao utilizar escravos-mercadorias para produzir outras mercadorias, a amortização do custo de aquisição implica a maximização do tempo de utilização do escravo, o que se torna dificilmente compatível com períodos prolongados de formação/instrução da força de trabalho.

3 - Em períodos nos quais o trabalho vivo constituía o insumo produtivo com mais peso na produção capitalista mas esta ainda não era dominante (isto é, quando várias formações sociais coexistiam ainda no mercado mundial), os investimentos de capital necessitavam de um aparelho politico capaz de compensar a insuficiente ou nula oferta de trabalho no mercado. Na Africa subsaariana do início da ocupação colonial não existia praticamente proletarização nas sociedades rurais. Essa "deficiência" causou, desde cedo, uma associação quase automática entre a implantação do trabalho "assalariado" nos territórios coloniais e a instalação de um aparelho político-militar de coacção. Durante a época do tráfico de escravos, os comerciantes europeus já tinham dependido de estados africanos, que aliás se consolidaram em função desse comércio; mais tarde, as autoridades coloniais tiveram de instalar os seus próprios aparelhos administrativos e maximizaram a eficiência da coação.

4 - Apesar da continuidade histórica do trabalho forçado na África sub-saariana, a legitimação politica e ideológica do segundo período de coação (o que coincidiu com a ocupação colonial) manifestou-se apresentando-se a si próprio como radicalmente do primeiro. A contradição das representações explica-se pela dificuldade em compatibilizar o abolicionismo jurídico (consensual na Europa desde meados do século 19) com a manutenção da coação.

Depois dos processos das abolições do tráfico e da escravatura legal - que nos estados europeus estavam terminados na década de 1870 - generalizou-se uma distinção ideológica radical entre trabalho livre e escravo, que se tornou marcante durante todo o século 20 e que perdura. A ideologia dominante, que assentava na representação do trabalho assalariado como única forma do trabalho "livre", passou a ver escravos em todas as sociedades pré-capitalistas (com essa etiqueta se estigmatizou o que restava das sociedades tradicionais, sobretudo fora da soberania europeia). Estabeleceu-se assim uma ruptura histórica onde, como se viu, existiu em muitos casos uma continuidade, pelo que a continuidade da coação exercida pelas administrações coloniais passou a exigir justificações novas. A ficção da "missão civilizadora" europeia e o carácter transitório (mas sempre sem prazo marcado) que era atribuído à obra colonial, tornou-se na principal delas 4 . Atribuindo uma acção "educativa" às administrações europeias (que mais tarde seria supostamente agradecida pelos beneficiários quando atingissem a maioridade histórica), criaram-se condições para uma legislação laboral desigual entre a metrópole e as colónias. Através desta brecha, as administrações europeias puderam adoptar nos seus territórios africanos legislações (e praticas) muito "pragmáticas".

5 - O período menos estudado e conhecido do longo processo do trabalho forçado africano é o último período, isto é, a fase colonial. Tendo o processo de descolonização tido início na Africa sub-saariana apenas nas décadas de 1960 e 1970, dificilmente

\footnotetext{
4 Como dizia um estudioso dos impostos coloniais: "É certo que os indigenas não pediram, não julgam necessaria essa civilisação que, ás vezes, lhes é imposta pela força, quando não é um pretexto para as mais revoltantes crueldades, como que que têem sido praticadas no Congo belga. Mas, através dos proprios crimes, e ainda por meio delles, a civilisação penetra e vae produzindo os seus beneficos resultados; e se, nos primeiros tempos, em que as lutas da conquista são recentes, em que as ambições dos colonos são mais vivas e fortes, e por isso irreflectidas e pouco escrupulosas, os indigenas só têem motivos para odiar os ferozes invasores do seu paiz, com o andar dos tempos, esquecidas as antigas violencias e depredações, os habitantes das colonias decerto abençoarão o forçado progresso que os habilitou ao convivio social com os povos mais adeantados n'um pé de possivel egualdade." Luís da Cunha Gonçalves, Revista Portuguesa Colonial e Maritima, $1907,19^{\circ}$ volume, $n^{\circ} 114$, p. 263
} 
haveria condições para que antes disso as universidades europeias o tivessem considerado enquanto objecto de estudo.

A ambiguidade trazida pelas legitimações ideológicas da segunda fase de coação foi decisiva para o atraso com que o próprio conceito de trabalho forçado colonial demorou a constituir-se. Por exemplo, quando em 1926 se votou na Sociedade das Nações a "Convenção sobre a Escravatura", constatou-se que, não havendo dúvidas da parte de nenhum dos estados membros quanto à condenação da "escravatura", muito se teria que discutir para definir consensualmente o "trabalho forçado". A S.D.N. encarregou a Organização Internacional do Trabalho de elaborar um inquérito para esse efeito. Quando, em 1930, um novo documento foi levado à discussão, a unanimidade ficou distante -93 votos a favor contra 63 abstenções. Escusado será dizer que três das quatro potências coloniais na África sub-saariana - a França, Portugal e a Bélgica - se abstiveram. Quanto à única das quatro que votou favoravelmente - a Inglaterra - sabe-se agora que a partir de 1932 o Colonial Office tranquilamente deixou de insistir com as administrações coloniais no sentido de implementar a convenção da OlT ${ }^{5}$

\section{O trabalho forçado colonial}

Considerando apenas o ponto de vista jurídico, aos Estados europeus escravagistas da fase do tráfico atlântico sucederam portanto Estados ideologicamente abolicionistas. Três factores ajudam a explicar por que razão as intenções abolicionistas das potencias marítimas ocidentais esmoreceram com a sua transformação em potencias coloniais africanas:

a) mantinha-se a baixa composição de capital nos ramos agrícolas e mineiros para onde eram canalizados os investimentos em Africa;

b) continuava a não existir mercado de trabalho em Africa, e assim seria até à completa ocupação do território pelas administrações coloniais;

c) O aparelho político-militar dos poderes coloniais tinha despesas impossíveis de saldar no quadro das limitações orçamentais metropolitanas.

Este último factor tem uma particular importância e convém desenvolvê-lo um pouco porque o papel do Estado foi muitas vezes negligenciado neste processo.

Grande parte da acumulação de capital do mundo moderno foi directamente realizada pelos aparelhos estatais. $O$ capital é uma relação social e a acumulação de capital pode ser feita tanto através de uma administração pública como privada. Contudo, a acumulação de capitais públicos ou privados só poderia ter início depois de um poder centralizado ter proporcionado as condições necessárias. As infra-estruturas materiais e imateriais necessárias a uma sociedade capitalista - vias de comunicação, rede hospitalar, sistema judicial, aparelho repressivo, etc. - representam elementos de capital fixo e de facturação de "falsas despesas" que, por serem em geral pouco ou nada lucrativos, não costumam ser directamente amortizados pelos capitais privados. Este conjunto de investimentos inclui aquilo que os fiscalistas designam por "externidades": bens ou serviços que, sendo indispensáveis à reprodução social, afectam não só os respectivos utentes directos mas também outros beneficiários - neste caso, as fracções de capital que sem a implantação dessas infra-estruturas não teriam condições para serem investidos nas colónias. ${ }^{\circ}$ 
No caso das sociedades coloniais o serviço público que garantia mais "externidades" à reprodução das relações capitalistas foi, como se deduz do que foi dito acima, a administração da violência "extra-económica" sobre as populações locais. Na ausência de mercado de trabaIho, a apropriação de mais-valia exigia uma pressão social apenas ao alcance de um aparelho estatal (ou para-estatal, se assim forem consideradas as companhias majestáticas que durante algum tempo substituíram provisoriamente e quase sempre sem êxito o Estado colonial).

A implementação destes serviços do Estado tinha custos para os contribuintes metropolitanos. No entanto, nas metrópoles, as fracções de capital não directamente beneficiadas pelos rendimentos coloniais tinham geralmente força suficiente para orientarem os orçamentos nacionais para outros destinos. Estando os interesses coloniais muitas vezes em posição de inferioridade na correlação de forças actuante no aparelho de estado, daqui resultou que a política seguida pela maioria dos governos centrais das potências com territórios "em valorização" fosse no sentido da auto-suficiência orçamental. Apesar das diligências dos interesses coloniais, a que se somava a pressão decorrente do clima de concorrências inter-imperialistas, a política habitual de todas as potências coloniais foi, até à reorientação trazida pela conjuntura do pós-II Guerra Mundial, transferir os custos em infra-estruturas materiais a realizar nas colónias para o regime da acumulação primitiva. Por outras palavras, as colónias deviam pagar-se a si próprias.

Um exemplo do Moçambique colonial: durante os 11 anos que corresponderam à fase mais intensa das operações militares da ocupação portuguesa nas regiões do Sul do Save e na Zambézia, o saldo liquido de transferências que o governo de
Lisboa autorizou para Lourenço Marques (a capital da colónia) foi inferior a ... 56 contos anuais (menos de $50.000 €$ a preços constantes). Mesmo assim, o governador Freire de Andrade não hesitava em afirmar sobre "subsídios ou auxílios enviados pelo Governo da Metrópole", que "justo é que não continuem e que estou fazendo todos os esforços para dispensar."

Obrigando as administrações a custearem o mais possível in loco os seus gastos de instalação, teve de se desenvolver a monetarização das relações sociais coloniais. As redes administrativas europeias tinham sido criadas em sociedades ligadas pelo valor de troca materializado, isto é, pelo dinheiro. Para que as suas extensões, os aparelhos de estado coloniais, pudessem funcionar enquanto pólos de poder, era-lhes absolutamente necessário encontrar - ou então introduzir - a circulação monetária nos territórios coloniais. A obtenção de receita local em numerário era uma condição sine qua non para que as administrações locais, (especialmente para as chamadas obras de "fomento"), se estabelecessem como parecia necessário. Nestas condições, financiar o Estado colonial implicava transformar as populações africanas em contribuintes solventes, fosse de que modo fosse.

É verdade que durante algum tempo, parte do excedente exigido às populações africanas e transformado em receita fiscal podia ser directamente consumido sem passar pela monetarização. Tratavase de uma captação primitiva de sobre-trabalho, útil apenas enquanto as necessidades do capital colonial não exigissem investimentos de maior grandeza ou de logística mais complexa. No entanto, muito rapidamente esta solução se esgotava: por exemplo, apesar da sua incontestável

7 ANDRADE, 1949: 139-141. Apenas em relação a uma das transferências metropolitanas (a de 1897-8) se regista que não inclui as despesas com expedições militares, pelo que se deverá entender que as restantes as incluem. 
serventia, nenhuma linha de caminho de ferro ou rede hospitalar poderia ter sido financiada com base apenas na corveia.

Note-se que poucas sociedades pré-coloniais africanas e asiáticas desconheciam em absoluto a circulação monetária; contudo, em poucas delas, o excedente social era regularmente monetarizado. Assim, a cobrança de receitas fiscais obrigou os administradores coloniais a acelerar duas importantes transformações sociais, que viriam alterar irreversivelmente a anterior divisão do trabalho. Por um lado, deveriam fazer com que parte do produto social se transformasse em excedente apropriado pela máquina fiscal, único modo de reproduzir e, se possível, valorizar os capitais públicos investidos; por outro lado, e não menos importante, deveriam generalizar a forma universal do valor de troca, o que implicava a introdução de um circuito monetário.

A implantação das redes fiscais coloniais foi deste modo o processo que levou, por si só, as sociedades pré-capitalistas a transformarem por completo o volume e a natureza do seu sobre-produto.

\subsection{O caso português}

As duas principais modalidades do trabalho forçado durante o período colonial foram, portanto, o contrato "com intervenção da autoridade" e o imposto. $O$ primeiro compatibilizou a figura jurídica do assalariado, fundamental para a reprodução do capital privado, com a quase ausência de oferta de trabalho ${ }^{8}$; o segundo financiou a máquina estatal colonial.

Para ilustrar estas duas modalidades, seguem-se dois exemplos de trabalho "livre" nas colónias, neste caso dois territórios portugueses: a) as plantações $S$. Tome e Príncipe, no caso do contrato; b) o cultivo do algodão no centro e norte de Moçambique, para o imposto.

a) Durante a década de 1890 a colónia portuguesa de STP tornou-se um dos maiores produtores mundiais de cacau. Entre 1894 e 1903, a sua produção cacaueira teve uma taxa de crescimento anual de $15,5 \%$ (contra 1,9 do Equador e 8,8 do Brasil). Nesta altura, as expectativas dos capitais cacaueiros apontavam para aumentos a curto prazo na taxa e na massa de lucro.

No entanto, grande parte das ilhas ainda estava por explorar. Calculava-se em 1905 que as explorações de uma das maiores companhias, a CIP, tinham atingido apenas $60 \%$ da sua produção potencial e que as de uma outra, a SAC (roças Porto Real no Príncipe e Santa Margarida

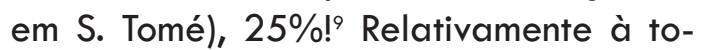
talidade do arquipélago, foi estimado nesse ano que as explorações agrícolas

\footnotetext{
8 Dialogo padrão de brincadeiras no porto da Beira, em Moçambique: "Você é contratado ou voluntário? - Nosso é voluntário. - Então veio trabalhar porque quis. - Não, patrão, nosso veio obrigado". CAPELA, 2010:289)

9 CIP e SAC são respectivamente os acrónimos da Companhia da llha do Príncipe e da Sociedade de Agricultura Colonial.
}

Quadro 1 - Produção de cacau em S. Tomé e Príncipe (toneladas).

\begin{tabular}{|l|c|c|c|}
\hline & $\begin{array}{c}\text { Produção } \\
\text { em 1905 }\end{array}$ & $\begin{array}{c}\text { Produção } \\
\text { potencial prevista }\end{array}$ & $\begin{array}{c}\text { \% da produção em } \\
\text { 1905 sobre a potencial }\end{array}$ \\
\hline Príncipe & $1.542,5$ & 5.868 & 26,3 \\
\hline S. Tomé & 9.921 & 23.941 & 41,4 \\
\hline Total do arquipélago & $11.463,5$ & $29.809,3$ & 38,5 \\
\hline
\end{tabular}




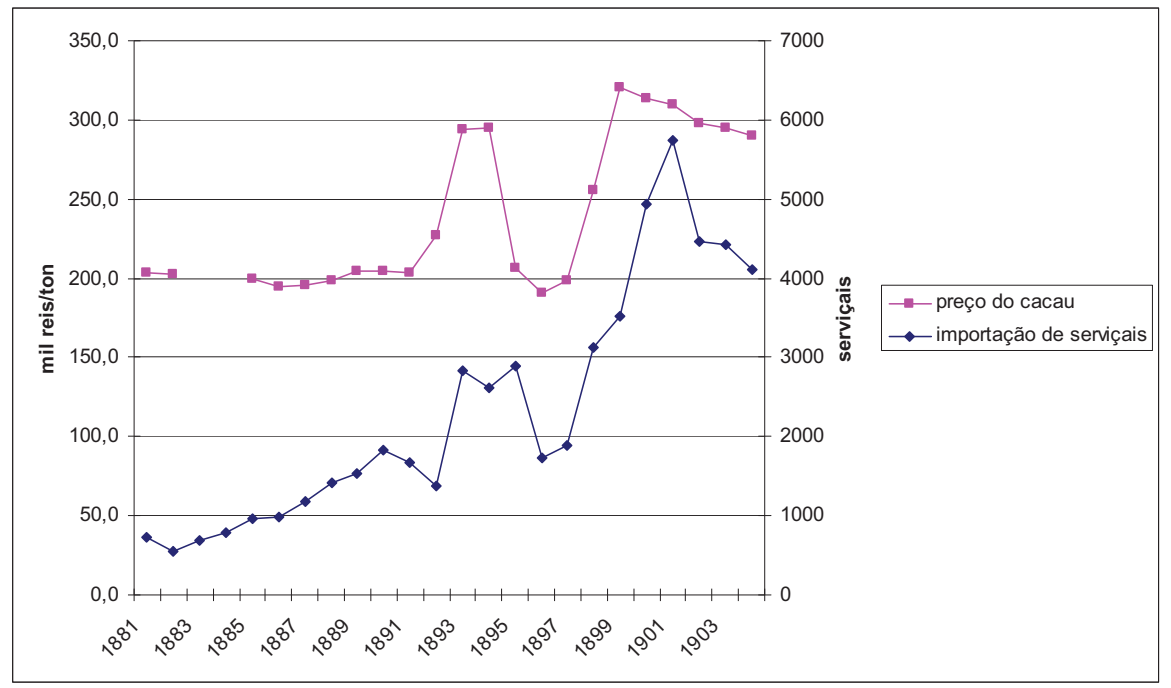

Fonte: para os preços do cacau, Estatistica de Portugal - Comércio do Continente do Reino e llhas Adjacentes com Paizes Estrangeiros e com as Provincias Portuguezas do Ultramar (1880-1904 - preços de exportação em Lisboa); para os serviçais, Boletim Oficial de S. Tomé (1880-1904)

Gráfico 1 - S. Tomé e Príncipe: preços médios do cacau em Lisboa e importação anual de serviçais (1881-1904).

estariam a produzir apenas cerca de $39 \%$ da sua plena capacidade, a atingir quando todas as áreas cultiváveis estivessem plantadas e em fase de maturação.

Como todos os ramos primários da época, a agricultura do cacau tinha uma dependência elevada de trabalho directo ${ }^{10}$. O citado relatório de 1905 contava 19.346 "serviçais" (nome dado aos trabalhadores rurais) na totalidade das roças e dava como necessário, para atingir a produção potencial estimada, um total de 32.834. As roças deveriam deste modo importar 13.488 novos trabalhadores: um aumento equivalente a $70 \%$ dos efectivos registados nesse ano.

Os investimentos das suas companhias seguiam de perto a evolução das cotações do cacau". Permitindo estas a obtenção de super-lucros, recrutar trabalhadores - fosse a que preço fosse - seria sempre uma condição necessária e suficiente

10 A contabilidade da SAC durante os anos 1899-1909 permite estabelecer uma correlação de 0,9718 entre o tempo de trabalho aplicado ao cultivo do cacau e a tonelagem obtida. SANTOS, 2006:298.

11 A contabilidade analítica da SAC permite estabelecer uma correlação de 0,7956 entre os preços do cacau e a alocação de tempo de trabalho às "capinas", tarefa do ciclo de cultivo do cacau de que mais dependiam as colheitas futuras. SANTOS 2006: 301. para a captação de rendas. ${ }^{12}$ As entradas de serviçais em S. Tomé evoluíram portanto em função das expectativas que as companhias tinham sobre as cotações, principal factor dos lucros. Para um período com informação estatística disponível - 1881-1904 - verifica-se uma associação significativa entre os preços nominais do cacau e as entradas de trabalhadores na colónia de S. Tomé ${ }^{3}$.

Simplesmente, aumentar em mais de dois terços a população de serviçais residente colocava uma grande dificuldade às firmas de S. Tomé e Príncipe. Dada a inexistência de uma oferta de trabalho local, todos os trabalhadores tinham de ser trazidos do continente africano e, por vezes, até de mais longe. Nenhum escalão administrativo português ignorava as particularidades do mercado de trabalho angolano, tanto em Benguela, como Luanda

12 "Os emigrantes de Angola, cuja introducção custava ao principio 40 mil réis apenas, subiram de preço, a ponto de de que annos depois se não podiam já introduzir por menos de 70 a 80 , e actualmente chegam a custar 110 . Ao passo que esse preço subia, augmentava naturalmente o custo da produção. Isso, porém, não era o peior. A escassez de braços é que está sendo o maior estorvo. As terras ultramarinas não se podem cultivar, porque não ha gente bastante para isso, e em taes condições o maior beneficio que se póde prestar á agricultura é resolver esta dificuldade." CIP, 1895:13-14

13 Coeficiente de Pearson $r=0,867596$. 


\section{S. Tome e Principe - movimento de serviçais}

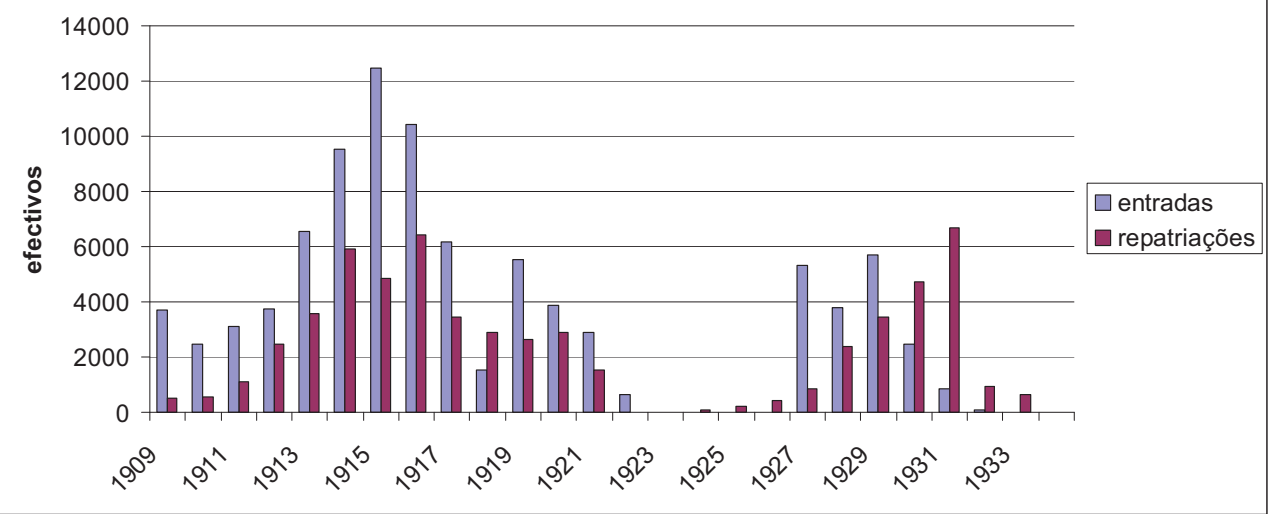

Gráfico 2 - S. Tome - movimento de trabalhadores.

ou S. Tomé: toda a oferta provinha da transformação de escravos comprados em serviçais contratados ${ }^{14}$. Massano de Amorim, o oficial encarregado de um inquérito às condições do comércio no planalto de Benguela, "esclareceu" deste modo o Governo Geral de Angola:

"Descrevendo o modo de vida do pequeno commerciante empregamos mais d'uma vez a palavra serviçal para designar uns pretos comprados e outros entregues como indeminisação de prejuizos causados.

Este termo - serviçal - não serve porem para designar um individuo contractado, perante a autoridade nos termos da lei.

Apezar da liberdade plena que a auctoridade permitte, como teremos occasião de ver, para estas tra(n)sações e arranjos o negociante arreceia-se ainda assim de ser encomodado pelo seu commercio illicito e criminoso e tanto nas suas conversas como nas suas relações commerciaes abstem-se de

14 Segundo os comerciantes do Dondo, nada distinguia a fase do tráfico legal da dos serviçais contradados: "Não vai ainda longe o tempo em que, acompanhando um certo numero dos taes emigrantes, seguia uma carta em que se dizia mais ou menos o seguinte: - "Remetto á consignação de V. $S^{a}$ tantos fardos, que espero collocará ao melhor dos meus interesses"!!! *O nome que isto merece, que lho dê cado um como entender; ao que hoje se faz ajusta perfeitamente a mesma classificação." COMMISSÂO..: 1904, 5. pronunciar a verdadeira palavra e ainda recioso de que the perguntem pelos contratos d'aquelles - serviçaes - nas suas contas, facturas e outros documentos de commercio (,) a palavra - rez - é empregada para designar os pretos recebidos ou comprados. $\mathrm{Ha}$ a consciencia do crime. Procuram occultal-o fazendo da palavra mascara. É frequente incluirem-nos com os bois e os fardos de borracha sob a mesma designação - volumes .

Alguns tém a coragem de lhe chamar - resgates. Serviçais ou rezes, volumes ou resgates, o termo exacto e unico que com verdade se pode empregar (é) este - escravos." 15

Esta situação manteve-se sem qualquer tipo de pressão internacional durante décadas mas a partir de 1904 a concorrência entre cartéis do cacau desencadeou uma campanha de imprensa na GrãBretanha hostil ao cacau de S. Tomé - a questão do "slave cocoa". Graças a ela, em parte, o governo português começou a controlar melhor as condições de recrutamento em Angola e sobretudo a organizar as repatriações dos trabalhadores

5 AHU - SEMU-DGU, maço 1106, relatório de Massano de Amorim, 1902, fी 20 
"exportados", que se tornaram regulares a partir de 1912. Mas as conjunturas do mercado do cacau eram voláteis e, portanto, as alterações entretanto verificadas eram também reversíveis: durante a recessão da década de 1930, quando as plantações deixaram de ter liquidez para recontratar em Angola, voltaram a reter impunemente os serviçais entretanto importados. Nessa altura, tendo S. Tome perdido a sua posição no mercado de cacau, o regresso destas praticas escravagistas "puras" também beneficiou de grande discrição jornalística, tanto nacional como internacional. A guerra do cacau já não passava por S. Tomé e não voltaria a haver campanhas de imprensa, como as do período entre 1904-1917.

\section{b) algodão e imposto em Moçambique}

Em Moçambique, o "imposto indígena" oscilou entre 24 e $40 \%$ de toda a receita provincial. Tratava-se portanto de um rendimento prioritário para o funcionamento do aparelho de Estado, o que torna compreensível a intensidade dos esforços administrativos associados à sua cobrança.

O grande problema que se colocava ao governo de Lourenço Marques era a desigualdade que as diferentes regiões da colónia tinham do ponto de vista fiscal. Durante a década de 1910, a cobrança do "imposto de palhota" (designação dada ao imposto cobrado à população africana) dependeu quase exclusivamente das cobranças feitas no Sul: os agregados do Centro e do Norte somados não chegavam a $10 \%$ da receita ${ }^{16}$. Esta dependência inicial relativamente ao Sul era o resultado da "monetarização" proporcionada pelos fluxos salariais trazidos

16 Parte dos territórios do norte e centro de Moçambique estiveram até 1942 sob administração de companhias masgestáticas e portanto fora da administração direta do Estado, que recebia apenas uma percentagem das receitas fiscais. No entanto, até ao final da década de 1930, tanto o imposto per capita como o total dos impostos diretos eram várias vezes menores nestas regiões que no Sul de Moçambique. pela emigração sazonal para ○ Rand. De acordo com as estatísticas da WNLA (a agência de recrutamento das minas da Africa do Sul), entre 1904 e 1929 as minas do Transvaal empregaram uma média anual de trabalhadores moçambicanos que oscilou entre 51.000 (1904) e 107.000 (1927). Era com base nos salários dos mineiros sazonais que o Estado realizava a sua cobrança fiscal.

No Centro e Norte da colónia, bem como nos territórios coloniais vizinhos, não havia investimentos de capital à mesma escala e portanto não havia empregos para garantir a monetarização suficiente para o pagamento do imposto. Para grande desespero dos administradores, a falta de liquidez afectava precisamente as regiões mais populosas da colónia.

\begin{abstract}
"Atiramos para lá com escribas e cobradores de imposto, quando ao mesmo tempo, deviam ter seguido alguns punhados de comerciantes, de industriais, de agricultores. De modo que, para o indigena, a situação apresenta-se nestes termos angustiosos: o Estado reclama-lhe os " 45 escudos da palhota sem que the dê possibilidade de grangea-los, recorrendo á exploração do solo ou apelando para o salariato. Dentro da fronteira, não encontra outra forma, nem de colocar os produtos, nem de alugar os braços. Eis como a população se vê condenada á emigração, arrastando-se em jornadas interminaveis, correndo Seca e Meca, buscando no estrangeiro os 5 xelins que the exigem as nossas autoridades." 17
\end{abstract}

O cultivo forçado do algodão foi a solução encontrada pelo Estado para fazer crescer a massa fiscal no Norte de Moçambique. Cultivando algodão em superfícies determinadas pela adminis-

17 CORREIA, 1937: (metonia) 
tração colonial e vendendo-o obrigatoriamente a companhias concessionarias por preços tabelados, a população adquiria a liquidez suficiente para pagar 0 imposto. Mas deve notar-se que, no início desta política, nem os industriais têxteis da metrópole, que podiam comprar algodão muito mais barato que o algodão colonial, nem as companhias concessionárias que compravam e exportavam o algodão, ganharam muito com o processo. A iniciativa do cultivo forçado do algodão foi estatal e teve motivações fiscais.

A pressão fiscal vê-se na irracionalidade da distribuição do algodão colonial. As regiões algodoeiras angolanas tinham in- contestavelmente mais aptidões algodoeiras que as moçambicanas, como sinteticamente se pode verificar pelo quadro 2 .

O quadro mostra como a intensificação algodoeira se fez do lado errado. Sendo durante este período o rendimento médio por hectare em Moçambique apenas 0,66 do de Angola, utilizaram-se em média do lado moçambicano 8 vezes mais trabalhadores e 5 vezes mais hectares de terreno que em Angola. A mesma irracionalidade aparece também nas assimetrias regionais do cultivo no interior de Moçambique, e de modo ainda mais esclarecedor.

quadro 3 resume os principais indicadores da distribuição regional da agri-

Quadro 2- Algodão em Angola e Moçambique: cultivadores, área cultivada e produtividade.

\begin{tabular}{|c|c|c|c|c|c|c|}
\hline Anos & $\begin{array}{c}\text { Angola } \\
\text {-Culti- } \\
\text { vadores } \\
\text { (milhares) }\end{array}$ & $\begin{array}{c}\text { Moçam- } \\
\text { bique } \\
- \text { Culti- } \\
\text { vadores } \\
\text { (milhares) }\end{array}$ & $\begin{array}{c}\text { Angola } \\
- \text { Área } \\
\text { cultivada } \\
\text { (milhares } \\
\text { de Ha.) }\end{array}$ & $\begin{array}{c}\text { Moçam- } \\
\text { bique-Área } \\
\text { cultivada } \\
\text { (milhares } \\
\text { de Ha.) }\end{array}$ & $\begin{array}{c}\text { Angola } \\
- \text { kgs/ } \\
\text { Ha }\end{array}$ & $\begin{array}{c}\text { Moçam- } \\
\text { bique- } \\
\text { kgs/ Ha. }\end{array}$ \\
\hline $1939-40$ & 66 & 534 & 49 & 192 & 269,4 & 106,4 \\
\hline $1940-41$ & 68 & 663 & 46 & 248 & 361,8 & 205,7 \\
\hline $1941-42$ & 92 & 557 & 58 & 228 & 278,1 & 307,7 \\
\hline $1942-43$ & 91 & 569 & 61 & 344 & 294,5 & 177,6 \\
\hline $1943-44$ & 86 & 791 & 55 & 267 & 393,6 & 239,0 \\
\hline $1944-45$ & 83 & 724 & 51 & 296 & 326,4 & 184,0 \\
\hline $1945-46$ & 67 & 564 & 41 & 238 & 312,4 & 259,9 \\
\hline
\end{tabular}

Fonte: JEAC - Alguns anos de actividade, Lisboa, 1946, pp. 22

Quadro 3 - Moçambique - distribuição regional da produção algodoeira em 1940-41.

\begin{tabular}{|l|c|c|c|c|}
\hline \multicolumn{1}{|c|}{$\begin{array}{c}\text { Distrito ou } \\
\text { Provincia }\end{array}$} & $\begin{array}{c}\text { Total de } \\
\text { cultivadores }\end{array}$ & $\begin{array}{c}\text { Área cultivada } \\
\text { (Ha.) }\end{array}$ & $\begin{array}{c}\text { Produção total } \\
\text { (toneladas) }\end{array}$ & $\begin{array}{c}\text { Rendimento - } \\
\text { kgs/ Ha }\end{array}$ \\
\hline Sul do Save & 8.652 & 2.530 & 722.078 & 285,4 \\
\hline $\begin{array}{l}\text { Beira (Manica e } \\
\text { Sofala) }\end{array}$ & 14.687 & 8.314 & 3.274 .726 & 393,9 \\
\hline Quelimane & 156.088 & 35.880 & 2.995 .885 & 83,5 \\
\hline Moçambique & 265.353 & 111.017 & 8.911 .844 & 80,3 \\
\hline Porto Amélia & 82.497 & 31.234 & 4.534 .719 & 145,2 \\
\hline
\end{tabular}




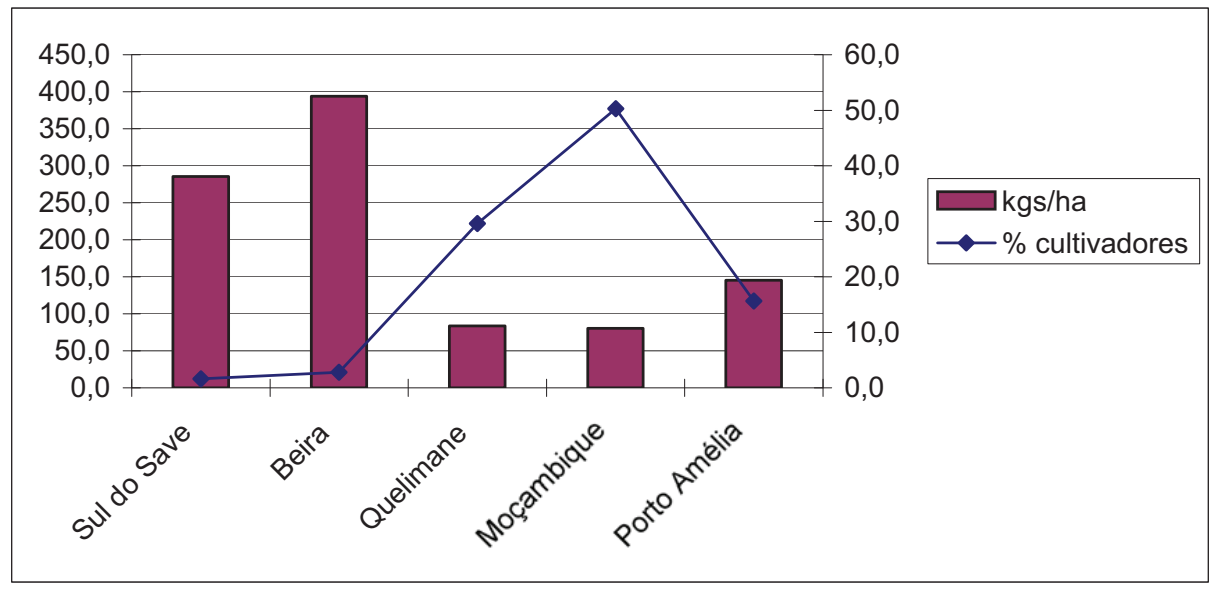

Gráfico 3 - Moçambique: cultivadores de algodão e produtividade por hectare em 1940-1941.

cultura algodoeira de Moçambique em 1941. Relembre-se que, devido à forte incidência da migração para $\circ$ Rand e em parte para a Rodésia do Sul, os distritos do Sul do Save eram os que tinham maior liquidez fiscal.

No Sul do Save, 1,5\% dos cultivadores produzia $3 \%$ do algodão. Em contrapartida, em apenas dois distritos (Moçambique e Quelimane) a maioria do algodão cerca de $58 \%$ - era produzida por $80 \%$ dos agricultores. Considerando apenas os casos extremos, verifica-se que, sendo o rendimento por hectare no distrito de Moçambique apenas 0,20 do da Beira, utilizaram-se no distrito do Norte quase 18 vezes mais cultivadores e 13 vezes mais hectares de terreno do que na Beira. Dificilmente se poderia conceber uma intensificação de cultivos mais contraditória com a racionalidade agrícola mas a partir da década de 1940 o objectivo estatal tinha sido atingido. Todas as regiões moçambicanas pagavam regularmente o seu imposto de palhota.

\section{CONCLUSÕES}

Os exemplos de trabalho forçado referidos foram retirados da administração colonial portuguesa mas esta não teve de modo algum o exclusivo de tais práticas. Nos territórios coloniais belgas, franceses, alemães e em muitos dos ingleses houve regularmente contratos "com intervenção da autoridade", cobranças violentas do imposto e cultivos obrigatórios.

O estudo das realidades coloniais apresenta hoje a utilidade da perspectiva comparada, que evidencia características também presentes nas violências laborais dos nossos dias :

a) de modo sistemático, as práticas do trabalho forçado encontram-se - paradoxalmente! - na produção capitalista, não nas sociedades ditas "atrasadas";

b) as práticas de trabalho forçado são utilizadas apenas em ramos de composição orgânica baixa;

c) implicam aparelhos políticos, públicos ou privados, de manutenção da coerção, dada a sua natureza "extra-económica";

d) formam um continuum de modalidades empíricas e até jurídicas, que tornam artificial a existência de uma fronteira nítida entre liberdade/escravidão

e) podem facilmente persistir enquadradas na ordem politica e jurídica internacional 
É verdade que as características do trabalho forçado colonial mostram também os seus limites históricos, tanto em Africa como noutras paragens. $O$ mundo mudou e desde a segunda metade do século $X X$ que o trabalho forçado se tornou residual em África. Assim teria que ser, considerando que o nível técnico da produção do setor primário assenta cada vez mais na automatização e no emprego de uma força de trabalho com um grau de formação elevado (já o mesmo não se passa com muitos ramos dos serviços, menos afectados pelo aumento da composição orgânica, e portanto mais vulneráveis às velhas práticas).

Uma outra conclusão desta comparação histórica é que a extinção das práticas coercivas pouco teve a ver com as abolições da escravatura. É também importante verificar como a persistência dessas práticas coercivas foi plenamente aceite pela opinião pública abolicionista. Vistas à distância, apareciam como um mal menor, um pouco como hoje o trabalho escravo contemporâneo é visto pelos telespectadores como um exotismo jornalístico. Mas talvez o mais urgente a reter desta comparação histórica seja que, numa sociedade como a nossa, as extinções do trabalho forçado podem ser reversíveis. O exemplo das plantações de S. Tomé na década de 1930 ou das distorsões fiscais feitas às sociedades camponesas africanas (que começaram no século 20 e persistiram até às descolonizações - e em alguns casos, mesmo depois delas) mostram-no sem deixar grandes dúvidas. $\mathrm{E}$ os vários milhões de novos escravos nas cidades e nos campos dos nossos dias voltam a confirma-lo.

\section{BIBLIOGRAFIA}

ANDRADE, Alfredo Augusto Freire d' 1949. Relatórios sobre Moçambique. Lourenço Marques, Imprensa Nacional de Moçambique, $2^{a}$ ed., 2 vols.
CAPELA, José 2010. Entrevista. Africana Studia, $n^{\circ}$ 14, Porto.

COOPER, Frederick. 1996. Decolonisation and African Society: the Labour Question in British and French Africa, Cambridge University Press.

JUNTA DE EXPORTAÇÃO DO ALGODÃO COLONIAL. 1946. Alguns anos de actividade. Lisboa.

LOVEJOY, Paul E. 2000. Transformations in Slavery. A history of Slavery in Africa. Cambridge University, Press.

MEILLASSOUX, Claude. 1995. Antropologia da Escravidão. O ventre de ferro e dinheiro. Jorge Zahar Editor, Rio de Janeiro.

PROVINCIA DO NIASSA. INSPECÇÃO DOS SERVIÇOS ADMINISTRATIVOS E DOS NEGÓCIOS INDìGENAS. 1938. Relatório duma Inspecção ás Circunscrições do Distrito de Moçambique pelo Inspector Pinto Corrêa (1936-1937). Lourenço Marques.

RIBEIRO, José Joaquim Teixeira. 1997 - Lições de Finanças Públicas. Coimbra, Coimbra Editora.

SALBANY, Armando. 1941. Alguns dados económicos sobre a cultura e comércio do algodão de produção indígena na colónia de Moçambique. Ministerio das Colónias, Junta de Exportação do Algodão Colonial, Delegação da Colónia de Moçambique. Lourenço Marques.

SANTOS, Maciel. 2005. Tempo de trabalho e lucro em S. Tomé e Príncipe - o caso da Sociedade de Agricultura Colonial (1899-1909), Centro de Estudos Africanos da Universidade do Porto, Porto: Campo das Letras, p. 289-314.

SANTOS, Maciel.2007. Imposto e algodão: o caso de Moçambique (1926-1945) Centro de Estudos Africanos da Universidade do Porto (coord.), Porto: Campo das Letras, p. 191-225

SURETCANALE, Jean. 1964. Afrique Noire Occidentale et Centrale. L'ère Coloniale (1900-1945). Éditions Sociales, Paris.

TESTART, Alain. 2001. - L'esclave, la dette ef le pouvoir. Editions Errance, Paris. 